\title{
Lajur Ampuh Membaca Bahasa Melayu(LAMBM) In The Teaching and Learning Process
}

\author{
Vijayaletchumy Subramaniam \\ Department of Malay Language, \\ Faculty of Modern Languages and Communication, \\ Universiti Putra Malaysia, Serdang Selangor, Malaysia \\ Nadia Shuhada
Department of Malay Language,
Faculty of Modern Languages and Communication,
Universiti Putra Malaysia, Serdang Selangor, Malaysia \\ Amirra Shazreena \\ Department of Malay Language, \\ Faculty of Modern Languages and Communication, \\ Universiti Putra Malaysia, Serdang Selangor, Malaysia
}

\begin{abstract}
Lajur Ampuh Membaca Bahasa Melayu(LAMBM) is an innovative teaching aid (ABM) for the basic learning in Malay Language created and produced to help Malay Language teachers to solve the problem of the inability to read in Malay Language among students. The implementation and formation of this process adopt the Research of Design and Development approach (DDR), QAIT Model by Slavin (1994) and ARCS Motivation Model by Keller (1988). This syllable basic learning approach employs five learning techniques in the form of games as the teaching aid, namely sound segment, syllable cards, syllable column basic board, syllable consolidation table and syllable poster. Every teaching aid has reading mastery levels starting from introduction to consonants and vowels, pronunciation of letter sounds, reading basic syllables, forming the combination of two syllables, syllable recovery, syllables consolidation and syllables enrichment. LAMBM has undergone a trial segmentt of 4 schools and obtained positive feedback from teachers. The test result at school also shows that LAMBM can engage students to read in Malay Language easily. With LAMBM approach in teaching and learning in class, weak students are able to involve themselves actively in the games while strengthening their mastery of syllable to further increase reading skills. LAMBM has a wide market size in and outside the country. The use of LAMBM increases students' individual and group participation. LAMBM can also engage weak students to take part actively in class activities. Thus, use of LAMBM in schools demonstrates innovative initiative in the 21st century teaching and learning.
\end{abstract}

Keywords : reading skills, students, teaching aid, innovation, LAMBM

\section{BACKGROUND}

Every student in Malaysia needs to master Malay Language well and be skillfull in reading, writing and verbal skills. This is because these are the three main components in Malay Language subject (Mohd Hafiz, 2016). These skills are very important in helping students during the teaching and learning of Malay Language and other subjects. Other than that, these three skills can also be used in daily life. Before students can actually write, they need to master the skills in reading first. Reading ability is not only regarded as fundamental to reach success in economy and social, but the school system itself regards it as the very essence for 
one to push himself or herself to a higher academic level. (Kamarudin Hj Husin, 1998). Reading mastery among primary school students is crucial because it can help students understand and learn new knowledge for future needs. This is due to the fact that reading is the core to all capabilities to explore the universe, strengthened by the significance of the knowledge culture (Wan Mohd. Noor Wan Daud, 1994).

The reading issue is still very seriously debated among the society in this country. Although we have been experiencing a surge of change in the globalised world, as well as mingling in the world of information technology and computerization, the reality is that reading significance cannot be neglected (Mohamad Sofee, 2007). Reading issues will affect students' capability to achieve better results in all subjects, including Malay Language subject. The Malaysian Ministry of Education (2000) has stressed on and paid attention to the process of reading, especially through the determination of the language skills that need to be achieved, as contained in the teaching and learning of Malay Language be it at the primary or secondary school level (Tamam Timbang, Zamri Mahamod, Nik Mohd. Rahimi Nik Yusoff \& Jamaludin Badushah, 2010).

\section{STUDY OBJECTIVE}

1. To identify reading skills in Malay Language among students through a diagnostic test.

2. To produce LAMBM teaching aid in reading skills.

3. To test the effectiveness of LAMBM teaching aid in overcoming the issue of reading among students.

\section{SIGNIFICANCE OF STUDY}

In the effort to resolve the issue of illiteracy among students, the use of LAMBM teaching aid in teaching and learning (PdP) can facilitate students to read, because each syllable and word prepared in this aid come from student's existing knowledge. Other than that, this teaching aid in the form of games also prepares some kind of reward, functioning to attract students' interests to learn syllables. Other than tapping into and attracting the interest of weak students, this teaching aid is also very important in urging passive students to participate more actively. LAMBM teaching aid is very user-friendly. Other than teachers, parents can also use this aid to implement the process of teaching at home together with their children.

\section{STUDY REVIEW}

In carrying out the process of teaching and learning of Malay Language among primary school students, teachers need systematic and effective teaching techniques so that they will engage students' focus. Most of the educators do not reach the objectives intended after they have taught the students and most of the students, in turn, cannot follow the whole process effectively. Upon this realization, various issues have emerged in the teaching and learning session.

The study about reading problems by Tamam Timbang, Zamri Mohamod, Nik Mohd Rahimi and Jamaludin Badushah (2010) seeks to identify factors causing reading problems among Year 6 students in Brunei Darussalam and identify the root of the problem despite its advanced and world-class education system. This qualitative study adopts the design of case study in various places. The qualitative data is fully obtained through some in-depth interviews. The subject of the study comprises of four students, four parents and six teachers from four primary schools in Brunei Darussalam. The elaboration, interpretation and conclusion of the data are carried out by looking at the theme, sub-theme and question of the study. Reliability is obtained using the Cohen Kappa correlation coefficient value. Data was analysed using Nvivo 7 and the study findings are reported in two sections, namely school profile and study 
participants also based on the study question. The findings show that the contributing factors to the existing reading problems among government primary schools' Year 6 students in Brunei Darussalam are caused by individual factor, psychological factor, teacher's teaching method, teaching period, environmental factor, and the reading textbook used. The implication of this study explains that the teacher's teaching method needs to be improved and increased to overcome the issue of reading among Year 6 students in Brunei Darussalam. This study only explains in general the factor and the root cause as to why students suffer from some reading problems. It is not stated in the study the solutions to the problems.

Other than that, in the study done by several researchers namely Tamam Timbang, Zamri Mohamod and Afendi Hamat (2011), they analyse the factor and the effect of reading issues among government primary school students in Brunei Darussalam. The subject, place and the method of study used are the same. The work has several objectives namely to identify the root of the reading problems and to identify the effect of these problems on students. The finding for the first objective is similar to the previous study. The contributing, factor to the existing reading problems among primary school students in Brunei Darussalam is caused by individual factor, psychological factor, teacher's teaching method, teaching period, environmental factor, and the reading textbook used. For the second objective, five effects of reading problems identified are failing in examination, affecting the learning of other subjects, the difficulty in sitting for the exams, psychological effects and the ranking in class. The study implication explains that the teaching of language teachers need to be improved and increased to overcome the reading issues among Year 6 students in Brunei Darussalam. The work, however, does not give any example of a suitable teaching method for teachers to improve their teaching as to solve students' reading problems.

Abdul Rasid Jamian (2011) carried out a study about the issue of reading and writing skills in Malay Language among primary school students in rural areas. This study has identified the issue of reading skills in Malay Language among primary school students in rural areas, identified the problem of mastering students' writing skills in Malay Language and looked into students' perception towards teachers' teaching in reading and writing. The study respondents comprise of 161 primary school students of Year 4 and 5 in rural areas in Negeri Sembilan, Pahang and Sarawak. This study comes in the form of descriptive survey using the questionnaire covering background information and problems students face in reading and writing skills. The finding shows that there are issues within students to master reading and writing in Malay Language, among which is the basic knowledge in reading and writing, the environment, and the teacher's teaching method. The finding further shows that students fail to understand the content of the information in the text read and they do not understand the meaning of the sentences they read. Meanwhile, the study finding on the issues surrounding writing skills shows that students cannot differentiate small from capital letters through detection and they do not identify with punctuation. In this work, researcher only explains the problem faced by students in reading and writing skills alone. This study does not offer any solution to these problems.

As opposed to the study by Nor Laila Kuslan (2014), she made an observation on the implementation of reading recovery activity in primary schools. The objective of this study is to identify the reading recovery activity done, factors that support its implementation and the factors that impede it from being realised. This study was carried out in a primary school in Shah Alam, Selangor. The study respondents comprised of eight groups: is 27 students from Year 1 (recovery class), school administrators (Headmaster and Deputy Headmaster (Academic)), Special Recovery Teachers, Year 1 Malay Language recovery teachers and students, Guidance and Counseling Teacher, Resource Center/Media teacher, parents also 
officers responsible for the Special Recovery Program in Malaysian Ministry Of Education and the Selangor Education Department. Data collection was made through interviews, observation and analysis of documents related to reading recovery program in the school sample. Three types of instrument were prepared for data collection namely Interview Guideline, Observation Guideline and Document Analysis Guideline. Data collection and analysis were carried out simultaneously to ensure data validity. The study finding shows that teacher, infrastructural facilities, elements related to teaching and learning of reading recovery and support are the four factors that support the success of reading recovery activity implementation. However, the teacher and the elements related to the teaching and learning of the reading recovery can also be an obstacle to the success, other than factors like student, parents, sound and spelling systems of the Malay Language itself and the influence of mother tongue. This study explains that the implementation of the reading recovery activity is supported by several parties and it also explains the factor that serves as the obstacle to the success of the activity. However, in this study, it does not state specific ally the aid that is used in the activity.

In overcoming the reading issues among students, an effective learning strategy would be essential. Tuzana Mohamad (2014) carried out a study about the effectiveness of Graded Reading Module to help Linus students to develop skills in reading (KVKV). This study carries several objectives which is to identify if there is an increase in KVKV open syllable words reading skill in the post-test after using the Graded Reading Module, identify if there is a difference in the KVKV open syllables words reading skills between Linus students of different races after using the Graded Reading Module, identify if there is a difference in the KVKV open syllable words as a reading skill between Linus students of different gender after using the Graded Reading, and identify the suitability of the Graded Reading Module on Linus students from the perspective of Year 1 teachers of Malay Language. In this study, the Graded Reading Module pays attention towards aspects of Malay Language reading skills involving the consonant-vowel-consonant-vowel open syllable words (KVKV). Data was obtained and measured through pre, post tests and learning session tests (treatment). Data was analysed descriptively using percentage. This study involves the difference in respondents' achievement in the post-test compared to the pre-test. The observation towards the students (respondents) and the interview on teacher-respondents are the qualitative data to see the suitability and interest of Linus students on the use of the Graded Reading Module as an alternative learning material to master KVKV word reading skill. The finding further shows that the Graded Reading Module has successfully been made the initial reading as the learning material especially for Linus students who still cannot master their reading. However, this study only focuses on Linus students only. This study cannot give significance to normal students who have the same problem of being weak in mastering the reading skills.

Other than that, the study carried out by Roslan Chin and Norahimah Yusoff (2017), a researched about the use of language learning strategy to master reading skills among students of special needs. A Malay Language teacher and six students from special needs class were selected as the subject in this research. The objective is to identify the language learning strategy (SPB) based on reading skills practised by the teacher with these special students. This study also intends to look into SPB based on the dominant use of the reading skills among teachers of special needs classes. Apart from that, the study is able to identify SPB based on the reading skills with the most effective use in teachers' practice towards students with special needs. This qualitative study employs the multicase single site study design. Data were obtained through document analysis, observation and interviews. The findings show that SPB based on reading skills using several techniques, namely techniques based on (a) letters, (b) pronunciation of syllables and the reading of meaningful words, (c) drilling, (d) language 
formula, (e) focused reading, (f) Visual, Audio, Kinesthetic, Tactile (VAKT), also (g) record and play, applied by the study subject to resolve the issue of reading skills mastery among students of special needs. This study prioritises the most dominant and the most effective strategy to be used by the teachers only. That said, the effectiveness of the strategy used by the teacher on the students in ensuring that weak students get to master the reading skills has not been identified in this study.

All in all, past studies have examined a great deal the problems surrounding students' reading skills in Bahasa or Malay Language. However, there are several gaps that need to be recognised in the entire work, one of which is that the solution for the problem has not been stated. Accordingly, previous studies have mentioned about the solutions to the reading problems among students. This leaves the gap to the researcher and hence, a study concerned with identifying the best solution to overcome students' reading problems.

\section{METHODOLOGY}

In this work, the formation of LAMBM teaching aid is produced through three aproaches, namely:

1. Design and Development Research (DDR)

2. QAIT Model by Slavin (1994)

3. ARCS Motivation Model by Keller (1988)

\section{Design and Development Research Approach (DDR)}

DDR is a concept of research that develops a development study systematically. This approach is basically formed through four phases (Richey dan Klien, 2017) :

a) PHASE one: needs analysis phase

b) PHASE two: design phase

c) PHASE three: development phase

d) PHASE four: evaluation phase (testing of useability)

\section{Qait Model by Slavin (1994)}

This model is fundamental to the formation of LAMBM influenced by four factors: Quality, Appropriateness, Incentive and Time. Slavin Model (1994) covers the input-output. In this study, input is based on QAIT model, while output is the increase learner's Malay Language reading skills.

\begin{tabular}{|c|c|c|}
\hline INPUT & PROCESS & OUTPUT \\
\hline Quality & $\begin{array}{l}\text { Quality : teacher needs to think } \\
\text { creatively in his or her teaching } \\
\text { techniques. } \\
\text { Appropriate } \\
\text { suitable with student's knowledge } \\
\text { level. } \\
\text { Incentive } \\
\text { reward system to engage students } \\
\text { Time : Ample time for teaching and } \\
\text { learning process. }\end{array} \mid \begin{array}{c}\text { The increase } \\
\text { in the mastery } \\
\text { of reading } \\
\text { skills in } \\
\text { Malay } \\
\text { Language } \\
\text { among } \\
\text { students }\end{array}$ \\
\hline
\end{tabular}

\section{ARCS Motivational Model by Keller (1988)}

This model is a form of a problem-solving approach to plan motivational aspects and also the learning scope in encouraging and defedning students' motivation to learn 
(Keller, 1987). This learning model is very closely associated with student motivation especially the motivation to master reading skills easily. ARCS itself is an acronym established from student's attitude, namely Attention, Relevance, Confidence, and Satisfaction. ARCS learning model is a form of learning that prioritises student's attention and adapts learning methods with student's existing knowledge and experience.

The scope of this study is confined or limited to testing the effectiveness of LAMBM as a teaching aid. Therefore, researcher only limits the study subjects to only weak students. They are Year 1 students from 4 schools, namely SJK(T) FES Serdang; SJK(T) Sg. Choh, Rawang; SK Sg. Pinang, Sarawak; and SJK(T) Batu Caves, Kuala Lumpur. To identify weak students in particular groups in class, students' reading skills in Malay Language are first tested using a diagnostic test. They are then asked to undergo the teaching and learning using LAMBM. This teaching aid is only limited to 5 aids only: sound segment, syllables card, syllables box basic board, syllables consolidation board and syllables poster. To evaluate the level of effectiveness of LAMBM on students' reading, the book Malay Language Smart Reading Kit has been used. Other than that, the questionnaire is also used by 110 teachers who are also serving as the subject of our study as to obtain some feedback towards the use of LAMBM teaching aid in the process of teaching and learning.

In this study, researcher uses several methods such as field study, observation and questionnaire, also the LAMBM teaching aid and the Malay Language Smart Reading Kit. The diagnostic test seeks to help the researcher to identify in detail the issues faced by the students in their Malay Language reading especially to target students. In this study, researcher has formulated a diagnostic test paper adapted from SJK(T) Vageesar in Kuala Selangor. Researcher has planned this test carefully and modified the items in the test paper based on the items that the students already know so that a more justified evaluation can be passed on to the students.

Other than that, a set of questionnaire comes in the form of feedback form to get the response and feedback from teachers about the effectiveness and the suitability of the use of LAMBM teaching aid in teaching and learning. The form has 20 questions and it is divided into five sections. Section I relates to the Sound Segment activity, Section II is about the Syllables Card activity, Section III is about Syllables Row Basic Board, whereas Section IV is related to the Syllables consolidation board activity and the final section is related to the Syllables Poster activity. Every section carries 4 questions.

LAMBM teaching aid comprises of 5 aids where the first one is sound segment, syllables card, syllables row basic board, the Syllables consolidation board and the syllables poster. The final study tool used in this study is the Malay Language Smart Reading Kit which is an instrument to test the level of readibility of the students after going through the teaching and learning process using LAMBM teaching aid. This instrument has four segments which are the segment of knowing the letters, the segment of letters, segment identifying single and the two meaningful syllables segment.

Data in this study is formed from both quantitative and qualitative methods. The quantitative data is taken from the diagnostic test, questionnaire and instruments to test students' readability. These data are collected through the diagnostic test carried out on the students to see their reading skill levels in Malay Language. Other than the Smart Reading Kit used to collect the data related to the effectiveness of LAMBM teaching aid to students, questionnaire instrument in the form of feedback form is also given to teachers to get their feedback about 
the effectiveness of the teaching aid. For the qualitative approach, data is gathered from the interviews. The interview session is done with the school teachers selected. This is to obtain some oral feedback with regard to the effectiveness of LAMBM teaching aid.

\section{STUDY FINDINGS}

\section{OBJECTIVE 1 : Students' Malay Language Reading Skills Level Through The Diagnostic Test}

A diagnostic test was done before researcher conducts the application of LAMBM techhnique to the target group. The test is done to identify the level of letter-literacy and readability of Malay Language among students. Other than that, researcher also carries out this test to know the level of mastery of the reading skills in Malay Language among students in the process of formal learning at school. A diagnostic test is done on the Year 1 students at 4 selected schools as the study sample. In a diagnostic test for SJK(T) Vageesar in Kuala Selangor, there are 12 levels of reading skills in Malay Language. The diagnostic test of reading levels in Malay Language covers the following :

Skill 1 : Capable of reading vowel and consonant.

Skill 2 : Capable of reading open syllables.

Skill 3 : Capable of reading words that have open syllables.

Skill 4 : Capable of reading closed syllables.

Skill 5 : Capable of reading words that have closed syllables.

Skill 6 : Capable of reading words that have closed syllables 'ng'.

Skill 7 : Capable of reading words with diphtongs.

Skill 8 : Capable of reading words with combined vowels.

Skill 9 : Capable of reading words that have digraphs and combined consonants.

Skill 10 : Capable of reading words with prefixes and suffixes.

Skill 11 : Capable of reading simple sentences.

Skill 12 : Capable of reading sentences based on stimuli.

However, in this study, researcher only chooses 3 skills only out of the 12 levels of skills, and they are skill 1, skill 2 and skill 3. Other than that, researcher also adds another skill which is the pronounciation of letter phonics. Therefore, in this study, researcher has classified Malay Language reading levels into 4 skills, which are :

Skill 1 : knowing vowels and consonants

Skill 2 : pronouncing letter phonics

Skill 3 : identifying syllables

Skill 4 : identifying two meaningful syllables

An emphasis is only given to these four skills because these skills are the basic skills for students at such an early stage in getting to know letters and it is the first step to learning how to read. The following is the results of the diagnostic test implemented at the four schools:

SCHOOL 1 : SJK(T) FES SERDANG (20 students)

\begin{tabular}{|c|l|l|l|l|l|l|l|l|l|l|l|l|l|l|l|l|l|l|l|l|}
\hline SUBJEC & \multirow{2}{*}{1} & 2 & 3 & 4 & 5 & 6 & 7 & 8 & 9 & 10 & 11 & 12 & 13 & 14 & 15 & 16 & 17 & 18 & 19 & 20 \\
\cline { 1 - 1 } & & & & & & & & & & & & & & & & & & & & \\
\hline 1 & & & & & & & & & & & & & & & & & & & & \\
\hline 2 & & & & & & & & & & & & & & & & & & & & \\
\hline 3 & & & & & & & & & & & & & & & & & & & & \\
\hline 4 & & & & & & & & & & & & & & & & & & & & \\
\hline
\end{tabular}


SCHOOL 2 : SJK(T) SG. CHOH, RAWANG (20 students)

\begin{tabular}{|c|c|c|c|c|c|c|c|c|c|c|c|c|c|c|c|c|c|c|c|c|}
\hline SUBJECT & 1 & 2 & 3 & 4 & 5 & 6 & 7 & 8 & 9 & 10 & 11 & 12 & 13 & 14 & 15 & 16 & 17 & 18 & 19 & 20 \\
\cline { 1 - 5 } LEVEL & & & & & & & & & & & & & & & & & & & & \\
\hline 1 & & & & & & & & & & & & & & & & & & & & \\
\hline 2 & & & & & & & & & & & & & & & & & & & & \\
\hline 3 & & & & & & & & & & & & & & & & & & & & \\
\hline 4 & & & & & & & & & & & & & & & & & & & & \\
\hline
\end{tabular}

SCHOOL 3 : SK SG. PINANG, SARAWAK (15 students)

\begin{tabular}{|c|c|c|c|c|c|c|c|c|c|c|c|c|c|c|c|}
\hline SUBJECT & \multirow[t]{2}{*}{1} & \multirow[t]{2}{*}{2} & \multirow[t]{2}{*}{3} & \multirow[t]{2}{*}{4} & \multirow[t]{2}{*}{5} & \multirow[t]{2}{*}{6} & \multirow[t]{2}{*}{7} & \multirow[t]{2}{*}{8} & \multirow[t]{2}{*}{9} & \multirow[t]{2}{*}{10} & \multirow[t]{2}{*}{11} & \multirow[t]{2}{*}{12} & \multirow[t]{2}{*}{13} & \multirow[t]{2}{*}{14} & \multirow[t]{2}{*}{15} \\
\hline LEVEL & & & & & & & & & & & & & & & \\
\hline 1 & & & & & & & & & & & & & & & \\
\hline 2 & & & & & & & & & & & & & & & \\
\hline 3 & & & & & & & & & & & & & & & \\
\hline 4 & & & & & & & & & & & & & & & \\
\hline
\end{tabular}

SCHOOL 4 : SJK(T) BATU CAVES, KUALA LUMPUR (30 students)

\begin{tabular}{|c|c|c|c|c|c|c|c|c|c|c|c|c|c|c|c|c|c|c|c|c|c|c|c|c|c|c|c|c|c|}
\hline SUBJECT & 1 & 2 & 3 & 4 & 5 & 6 & 7 & 8 & 9 & $\begin{array}{l}1 \\
0\end{array}$ & 1 & , & $\begin{array}{l}1 \\
3\end{array}$ & 1 & $\begin{array}{l}1 \\
5\end{array}$ & $\begin{array}{l}1 \\
6\end{array}$ & \begin{tabular}{l|l}
1 & \\
\end{tabular} & $\begin{array}{l}1 \\
8\end{array}$ & $\begin{array}{l}1 \\
0\end{array}$ & \begin{tabular}{|l|}
2 \\
0
\end{tabular} & & 2 & & $\begin{array}{l}2 \\
5\end{array}$ & $\begin{array}{l}2 \\
6\end{array}$ & $\begin{array}{l}2 \\
7\end{array}$ & $\begin{array}{l}2 \\
8\end{array}$ & & $\begin{array}{l}3 \\
0\end{array}$ \\
\hline LEVEL & & & & & & & & & & $\mathbf{0}$ & & 2 & 3 & & 5 & & & & & & 2 & & & 5 & & & 8 & & \\
\hline 1 & & & & & & & & & & & & & & & & & & & & & & & & & & & & & \\
\hline 2 & & & & & & & & & & & & & & & & & & & & & & & & & & & & & \\
\hline 3 & & & & & & & & & & & & & & & & & & & & & & & & & & & & & \\
\hline 4 & & & & & & & & & & & & & & & & & & & & & & & & & & & & & \\
\hline
\end{tabular}

PETUNJUK :

Menguasai

Tidak menguasai

\section{Results of Diagnostic Test}

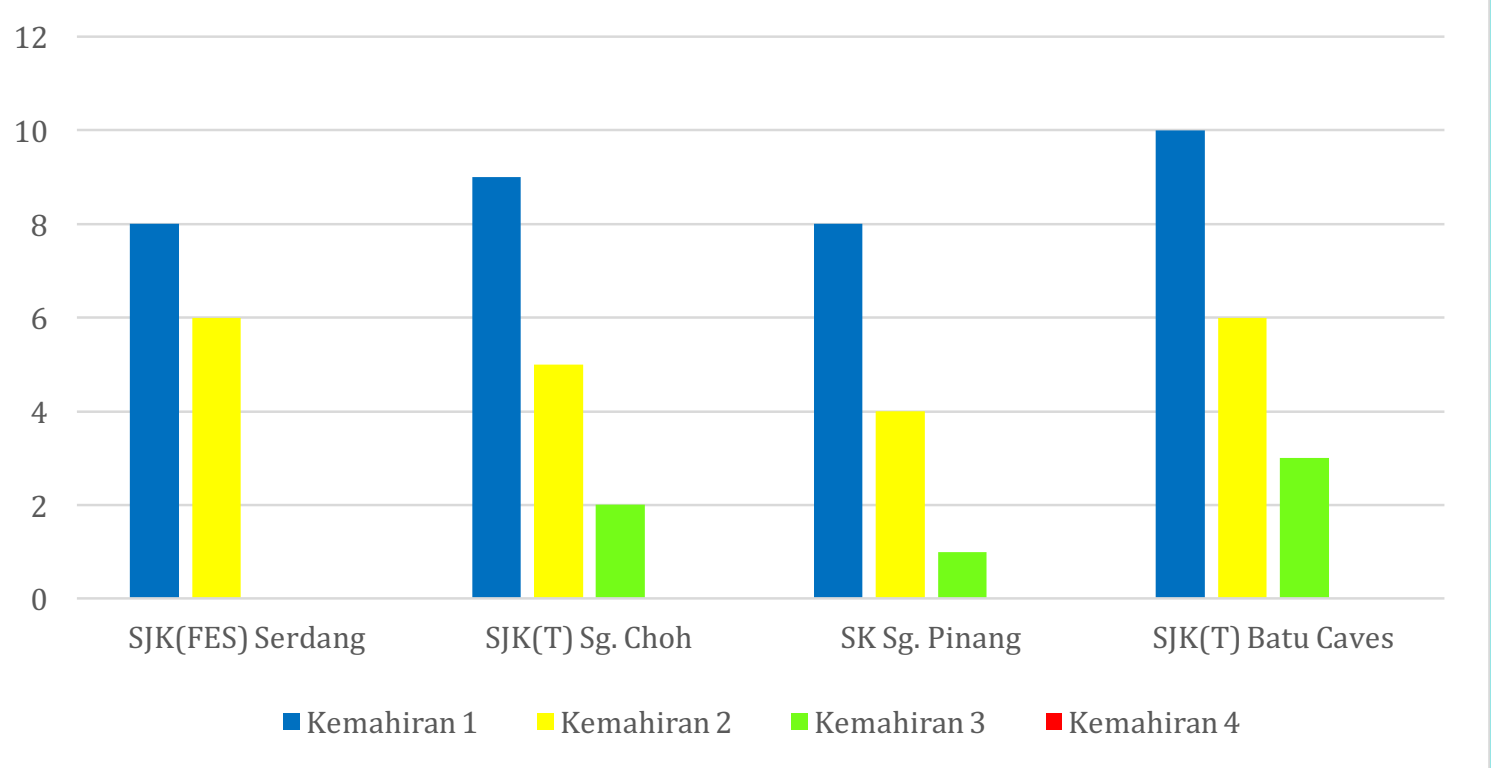

The above graph shows the diagnostic test results done in all the four schools involved. Based on the graph, all in all, most students from 4 schools have mastered level 1 test which is knowing vowels and consonants. Next, several students are at moderate level in mastering level 2 skill which is pronouncing letter phonics. A small number of students in the four schools 
are at a very weak level which is the third level of reading skill which is the syllables identification skill. For the fourth reading skill, none of the subjects has mastered it.

\section{OBJECTIVE 2}

\section{LAMBM teaching aid in reading skills}

In this study, the formation of LAMBM teaching aid is produced through three approaches, and they are :

1. Design and Development Research (DDR)

2. QAIT Model by Slavin (1994)

3. ARCS Motivational Model by Keller (1988)

\section{Design and Development Research (DDR)}

Design and Development Research (DDR) is a research concept that develops a development study systematically. Fundamentally speaking, this approach is formed through four phases namely: (Richey dan Klien, 2017) :

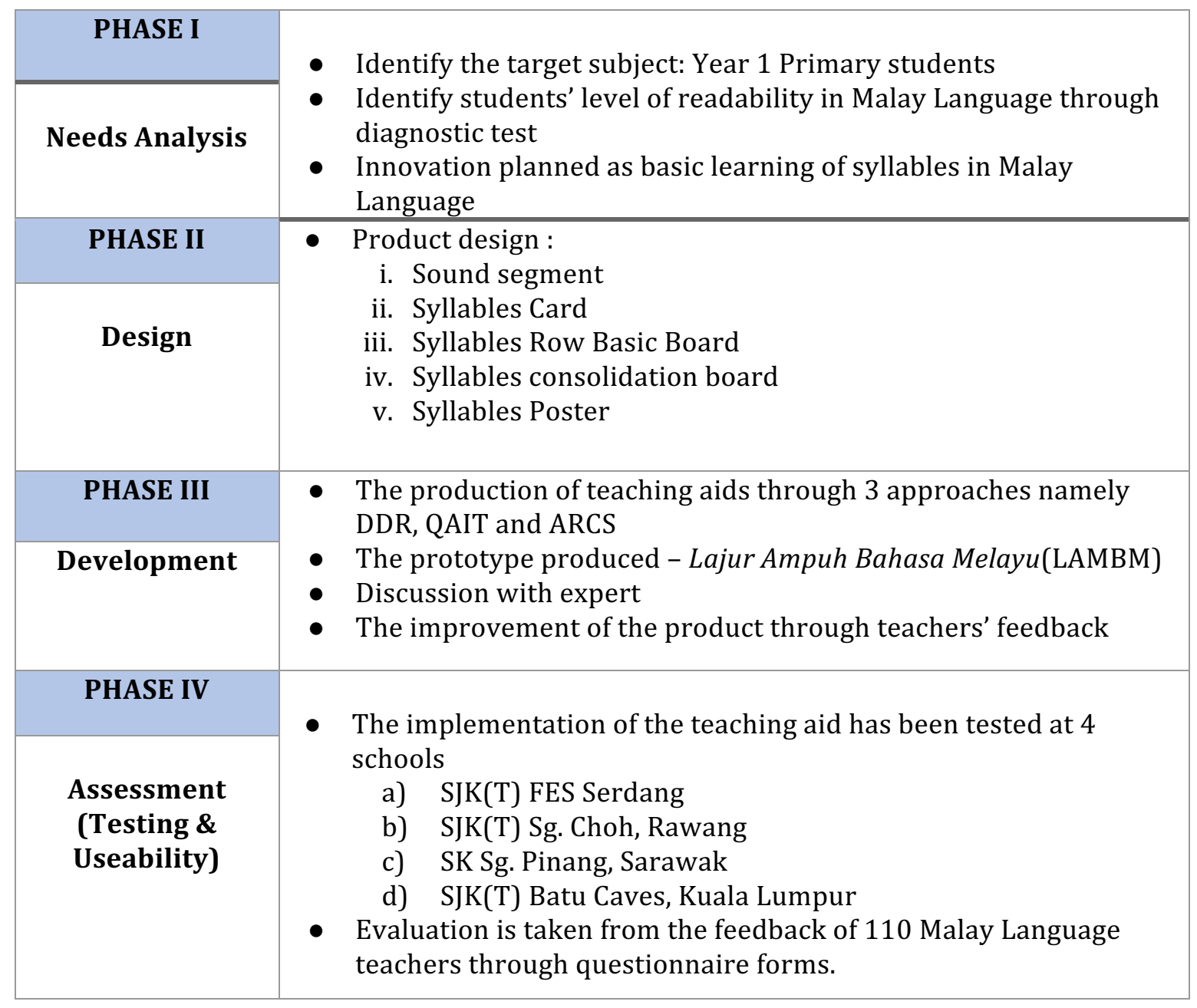

\section{Qait Model by Slavin (1994)}

The QAIT model by Slavin (1994) is influenced by four factors namely Quality, Appropriateness, Incentive and Time. Slavin's model (1994) covers the input-output. In this study, input is based on QAIT model whereas the output lies in the increase in the mastery skills when it comes to reading in Malay Language among students. 


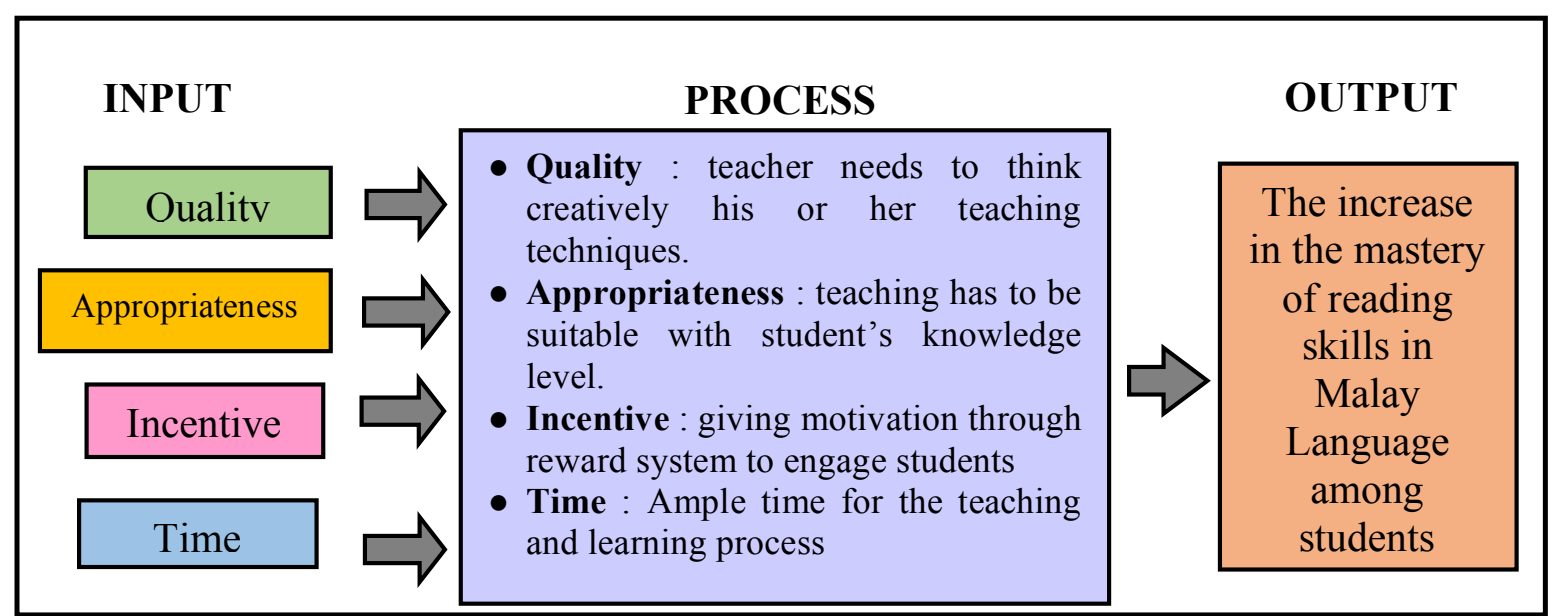

\section{Quality}

Quality encompasses the quality of teaching, which is a level of information or skill presented so that the students will find it easy to learn it. The teaching quality encompasses a network in which an educator can think creatively in carrying out interesting teaching and learning techniques so that teacher's delivery of the lesson would be engaging and can help them to remember their lessons. Teachers need to deliver lessons systematically and require new techniques with the help of interesting teaching aid. The finding shows that LAMBM teaching aid is capable of this, where it helps students to become more focused in their learning. This is because LAMBM has its own appeal and it gives an opportunity to every student to do PdP session in the form of games.

\section{Appropriateness}

This refers to level, whereby a teacher has to ensure that a student is ready to learn new lessons (which means that they have the skills and related knowledge to learn it) but they have not learned it yet. In other words, the teaching level must be appropriate when the lesson is not too difficult or too easy for a student. It is a fact that a weak student would not be able to follow the lesson if the level of teaching is high, while low level of teaching will make a student bored and lose focus towards his or her studies. In this work, LAMBM product is very much appropriate to be used in teaching weak students. This is because this product is designed based on student's existing knowledge and every segment in this product has 5 levels according to the appropriateness of student's readability level in Malay Language.

\section{Incentive}

Incentive means the level when a teacher makes sure that a student is motivated to act upon tasks based on instructions given and to learn the material presented. Two ways of motivating students are firstly by engaging them through fun teaching and secondly through rewards and compliments. LAMBM product has both these criteria. It is a teaching process that is produced in the form of game and every segment in this game prepares rewards to engage students to learn syllables.

\section{Time}

The aspect of time refers to the time when students are given enough time to learn a material presented. Teacher's teaching is influenced by two time factors which is the first one, the time allocated by the school for the teacher to teach a subject, and the second one is the time-ontask or engaged time, meaning the time used by the teacher to teach and the time used by a student to learn knowledge or skills. (Shahril, 2005). The teaching and learning process using LAMBM is influenced by the second factor. Teacher will conduct the teaching process using the 
LAMBM aid, under a stipulated time, whereas students will use the time given by the teacher to perform activities.

\section{ARCS Motivation Model by Keller (1988)}

ARCS learning model is a form of problem-solving approach to plan motivational aspects and learning scope in encouraging and maintaining student's motivation to learn (Keller, 1987). This learning model is inextricably linked with student's motivation especially the motivation for students to master the reading skills easily. ARCS learning model is a form of learning that stresses on student's attention and it adapts the learning method with the student's existing knowledge. In this study, the production of LAMBM teaching aid also employs this model approach.

\section{Attention}

Attention is a form of instruction to obtain student's attention in the process of teaching and learning in class. Student's attention in learning can be seen through his or her interest and focus shown when the teacher is teaching. In this study, the study subjects are observed to have given their attention and to have focused because they have shown interest towards the LAMBM teaching aid adopted. An interesting form of teaching aid, which is colourful and can be touched and held will tend to make students more interested and more eager to learn.

\section{Relevance}

Relevance here can be interpreted as an association or the appropriateness between the learning process and the learning experience gained by a student. The association and the appropriateness of a material given can encourage motivation in students because they can feel that the process of teaching and learning will have some benefits for them. In this work, every aid is prepared based on student's existing knowledge. This is very relevant because, it is very appropriate for students to learn something that they know about. If the materials presented to them are outside their scope of knowledge and thinking, they will easily get bored and it will not be beneficial to them.

\section{Confidence}

In the process of teaching and learning at school, to fulfil the academic requirement of passing in any given subject, the teacher will have the tendency to instruct students to perform drilling or exercise and memorise a topic that is beyond the students' knowledge capability. Teachers should be able to use effective learning strategies so that students will find it easy to learn. This study prepares a teaching aid for teachers to help them teach more easily especially to weak students.

\section{Satisfaction}

Satisfaction means the feeling of happiness in understanding something learned. This is a positive feeling for a student when he or she is appreciated and valued. This can instil selfconfidence in the student by arousing their spirit to continue following the process of learning. This is spurred by motivational rewards like positive wishes ("good", "well done", "congratulations"), smiles, rewards or compliments. In this study, researcher prepares the reward for students for every aid used. This can be interesting to students to take part more actively in the learning session.

\section{LAMBM teaching aid}

LAMBM teaching aid is an innovation from the researcher as a new teaching tool in helping students to master the skills of reading in Malay Language easily. In this study researcher tries to help weak students in their reading in Malay Language increase their reading skills by 
learning to use more interesting teaching and learning techniques (PdP). LAMBM technique involves 5 teaching aids namely:

\section{Sound Segment}

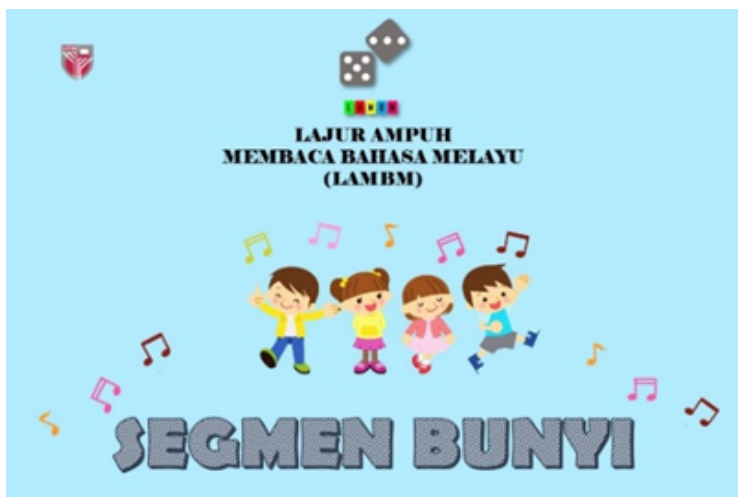

Sound Segment is a video related to the exposure to vowel and consonant sounds accompanied by music and songs. Through this video show, students get to pronounce vowel and consonant sounds one by one clearly. This video functions as an inductive set before the class begins. It seeks to engage students' interest to learn the topic that is going to be learned, and then train students to pronounce the letters as they sing. This aid helps students to master the first and second skills, which is knowing vowel and consonant letters and pronouncing letter phonics.

\section{Syllables Card}

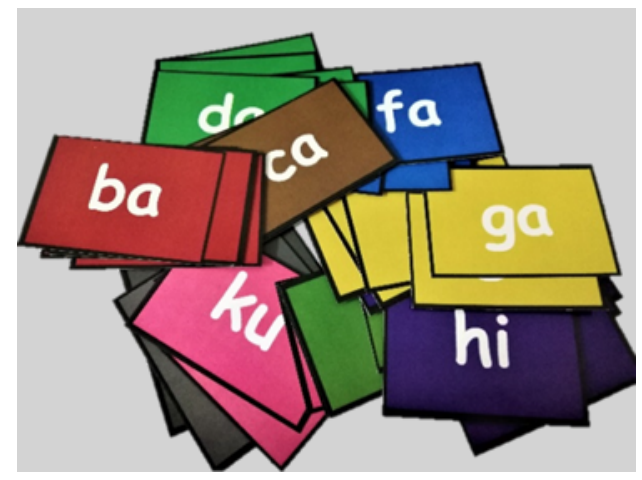

Syllables Card is a teaching aid comprising of colourful cards of square size containing KV open syllables. (consonant + vowel). These cards function to introduce the students to KV syllables. This aid can also train students to see and pronounce syllables through teacher's guidance and when teachers correct their mistakes in pronouncing KV syllables through drilling (repetitive activity). Students will be asked to spell, read and pronounce the syllables repetitively and try to combine the syllables into two open syllables which is KVKV. The drill helps students to remember better the combination of KV sound after drilling is done according to certain syllables classes. This aid also helps students to master the third skill, which is identifying syllables. At the same time, this aid can also help students to master the second skill, namely to pronounce letter phonics, and it helps in terms of pronouncing open syllables sounds. 


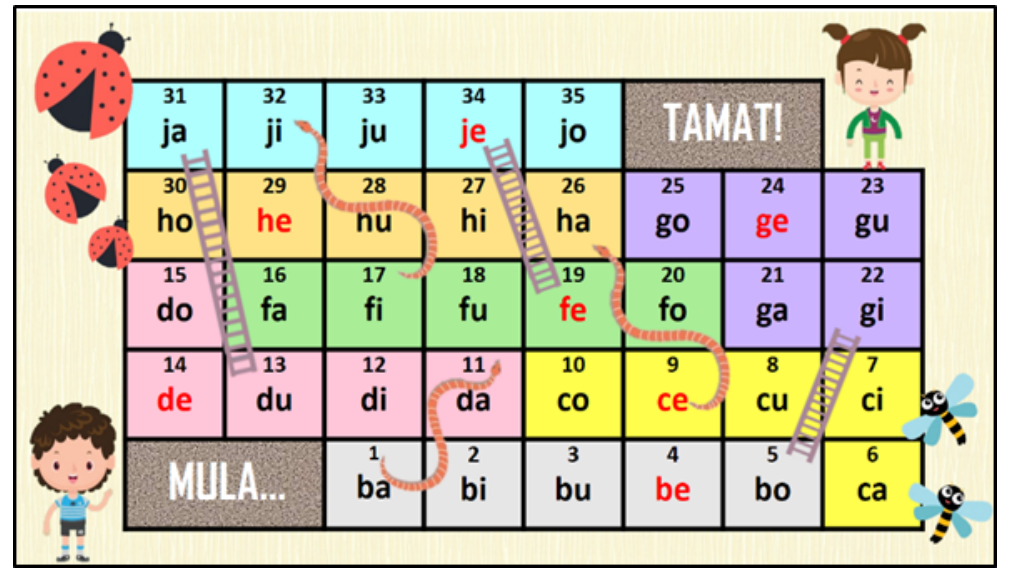

Students will be prescribed with aids like numbered dice and syllables row basic board. The board has ros of boxes with KV open syllables that are arranged at random. It is played like snake and ladder and this activity is performed in pairs. Through these aids, students can see, read and pronounce and make the sound of the syllable on the spot, determined by the movement of the dice. On every box that it stops, students need to spell, read and pronounce the syllables from the initial ones to the syllable box where it stops. This activity helps students to read and pronounce all syllables on the board with their partner and helps them remember KV syllables better with the help of their peers. This aid can also engage the students to learn syllables with their peers through the syllables basic board. This helps students to master the skill of identifying vowels and consonants through the syllables on every box, which is the combination of vowels and consonants. Other than that, students are able to master the skill phonic pronunciation, where students will be able to read and pronounce syllable sounds on the box. Next, students will be able to master the third skill which is the skill to identify syllables.

\section{Syllables Consolidation Board}

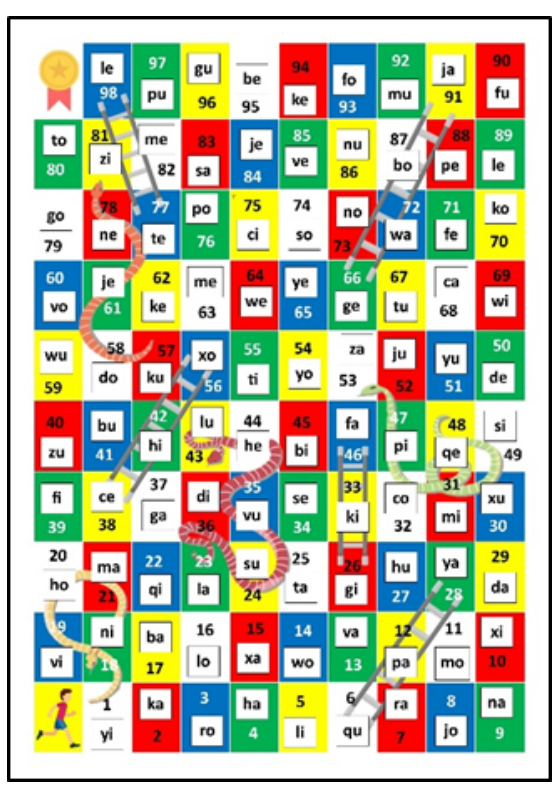

Students will be provided with teaching aids like numbered dice, syllables dice and syllables consolidation board. The syllables consolidation board in the form of boxes laid in rows of boxes with KV open syllables is arranged at random and there are more syllables on this board than the ones on the basic board. The function is to consolidate students' mastery in pronouncing basic syllables. In this game, students will learn to combine one syllable to 
become two open syllables (KVKV). The function of the numbered dice is for the movement on the snake board. The syllable box on which the dice stops is the first syllables, whereas the second syllable will be determined through the rotation of the syllables dice. Students will jot down the syllables and re-read them. The purpose of this aid is to train students to pronounce the combination of two KVKV syllables which does not have a meaning repeatedly to consolidate students' pronunciation mastery through games. This activity also trains students to work together and mutually helps peers and also boosts the confidence in students to work actively in groups. Other than that, it can help students to continue with syllables learning together with groups through more challenging acstivities. This aid helps students to master the skills of identifying vowels and consonants through syllables on each box, which is the combination between vowels and consonants. Other than that, students are also able to master their phonic pronunciation, in which students will read and pronounce syllable sounds in the boxes. Next, students will get to master the third skill which is the skill of identifying the syllables.

\section{Syllables Poster}

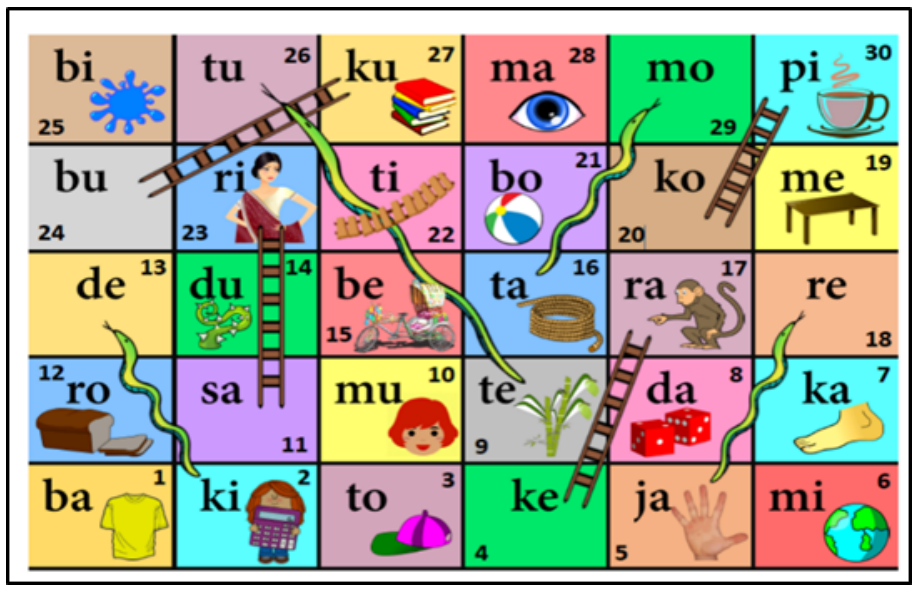

Students will be presented with teaching aids like numbered dice, syllables card and syllables poster in bigger size. This poster comes in the form of columns and boxes with KV open syllables. In this game, students will learn to combine two open syllables (KVKV) that are meaningful. The function of the numbered dice is to facilitate the movement on the poster which represents one syllable and to get meaningful KVKV, they have to look for the second syllable, through the syllables card. The combination of two meaningful syllables will be helped by the existence of images or pictures prepared in each box on the poster. This game is designed to instil students' confidence to read syllables when the dice's movement stops in front of friends and it trains students to combine syllables $\mathrm{KV}+\mathrm{KV}$ to become a meaningful word. Also, this game also helps students to remember and to add to their Malay Language vocabulary in their knowledge. This aid can help students to master all four skills namely the skill to identify vowels and consonants through spelling, the skill to pronounce phonics through the pronounciation of letter sounds when students read the syllables, the skill to identify the syllables through syllables reading on every box, and the skill to identify two meaningful syllables when students combine two syllables to become one meaningful word.

\section{THE EFFECTIVENESS OF LAMBM TEACHING AID IN TEACHING AND LEARNING.}

With the use of LAMBM in the process of teaching and learning, the level of effectiveness of this teaching aid can be measured and evaluated through students' reading mastery after applying the LAMBM technique using instruments like Reading Malay Language reading Kit. Students are required to re-read the book after undergoing the PdP process using LAMBM aid. The book has 4 segments and they are : 
Segment 1: know vocals and consonants (skill 1)

Segment 2: pronunciation of phonics (skill 2)

Segment 3: the introduction of one syllable (skill 3)

Segment 4: the introduction of two meaningful syllables (skill 4)

The following are the results for students' reading before and after using the LAMBM teaching aid

\begin{tabular}{|c|c|c|c|c|c|c|c|c|}
\hline SCHOOL. & \multicolumn{2}{|c|}{$\begin{array}{c}\text { SJK(T) FES } \\
\text { SERDANG } \\
\text { (20 people) }\end{array}$} & \multicolumn{2}{c|}{$\begin{array}{c}\text { SJK(T) SG. CHOH, } \\
\text { RAWANG (20 } \\
\text { people) }\end{array}$} & \multicolumn{2}{c|}{$\begin{array}{c}\text { SK SG. PINANG, } \\
\text { SARAWAK } \\
\text { (15 people) }\end{array}$} & \multicolumn{2}{c|}{$\begin{array}{c}\text { SJK(T) BATU } \\
\text { CAVES } \\
\text { (30 people) }\end{array}$} \\
\hline SEGMENT & Pre & Post & Pre & Post & Pre & Post & Pre & Post \\
\hline $\mathbf{1}$ & 8 & 18 & 9 & 20 & 8 & 19 & 10 & 27 \\
\hline $\mathbf{2}$ & 6 & 18 & 5 & 18 & 4 & 17 & 6 & 25 \\
\hline $\mathbf{3}$ & 0 & 15 & 0 & 18 & 1 & 17 & 3 & 22 \\
\hline $\mathbf{4}$ & 0 & 13 & 0 & 16 & 0 & 15 & 0 & 22 \\
\hline
\end{tabular}

The reading of Bijak Membaca for 4 schools before using LAMBM Aid In Teaching and Learning

12

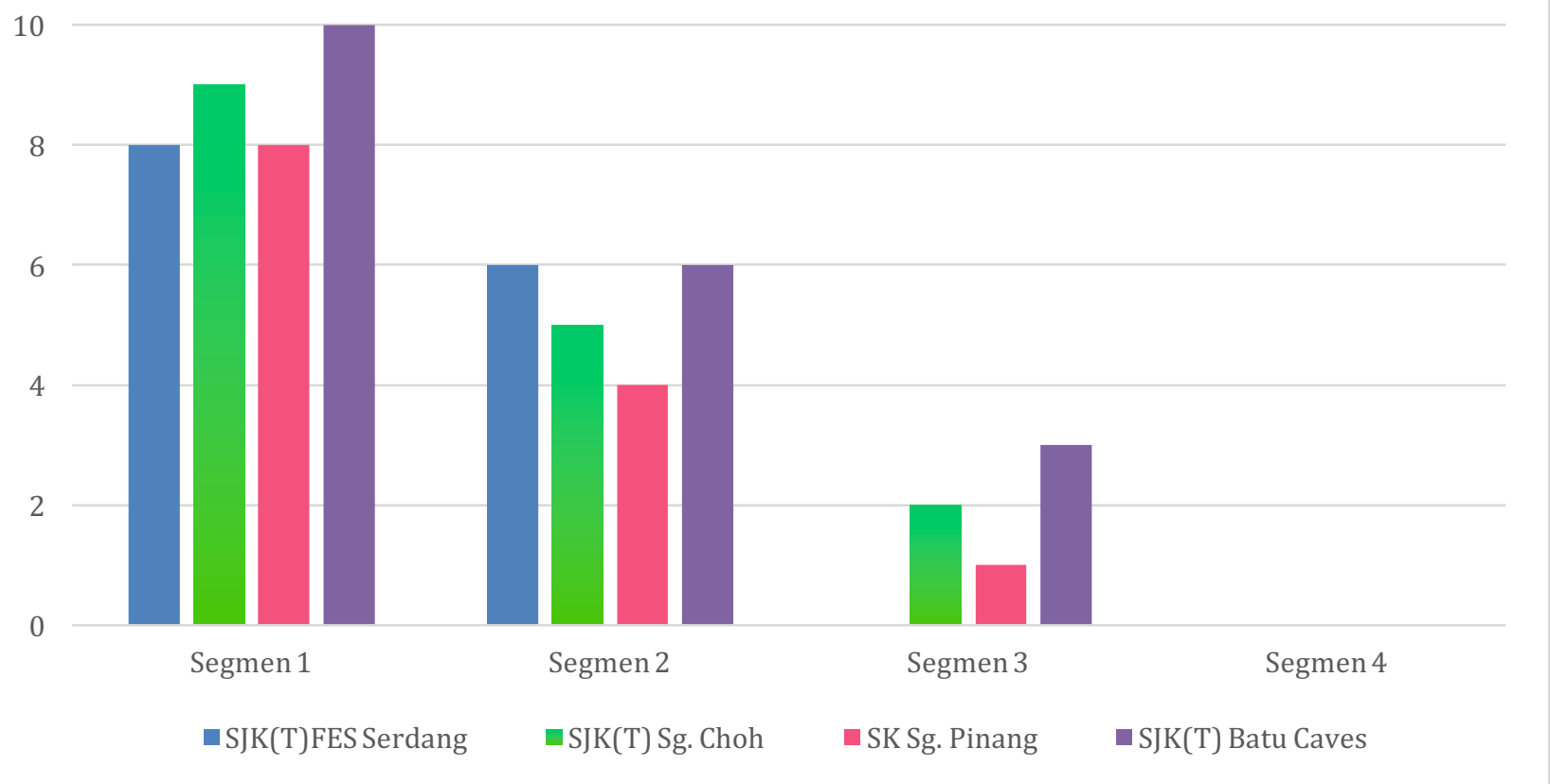




\section{The reading of Bijak Membaca for 4 schools after using LAMBM Aid In Teaching and Learning}

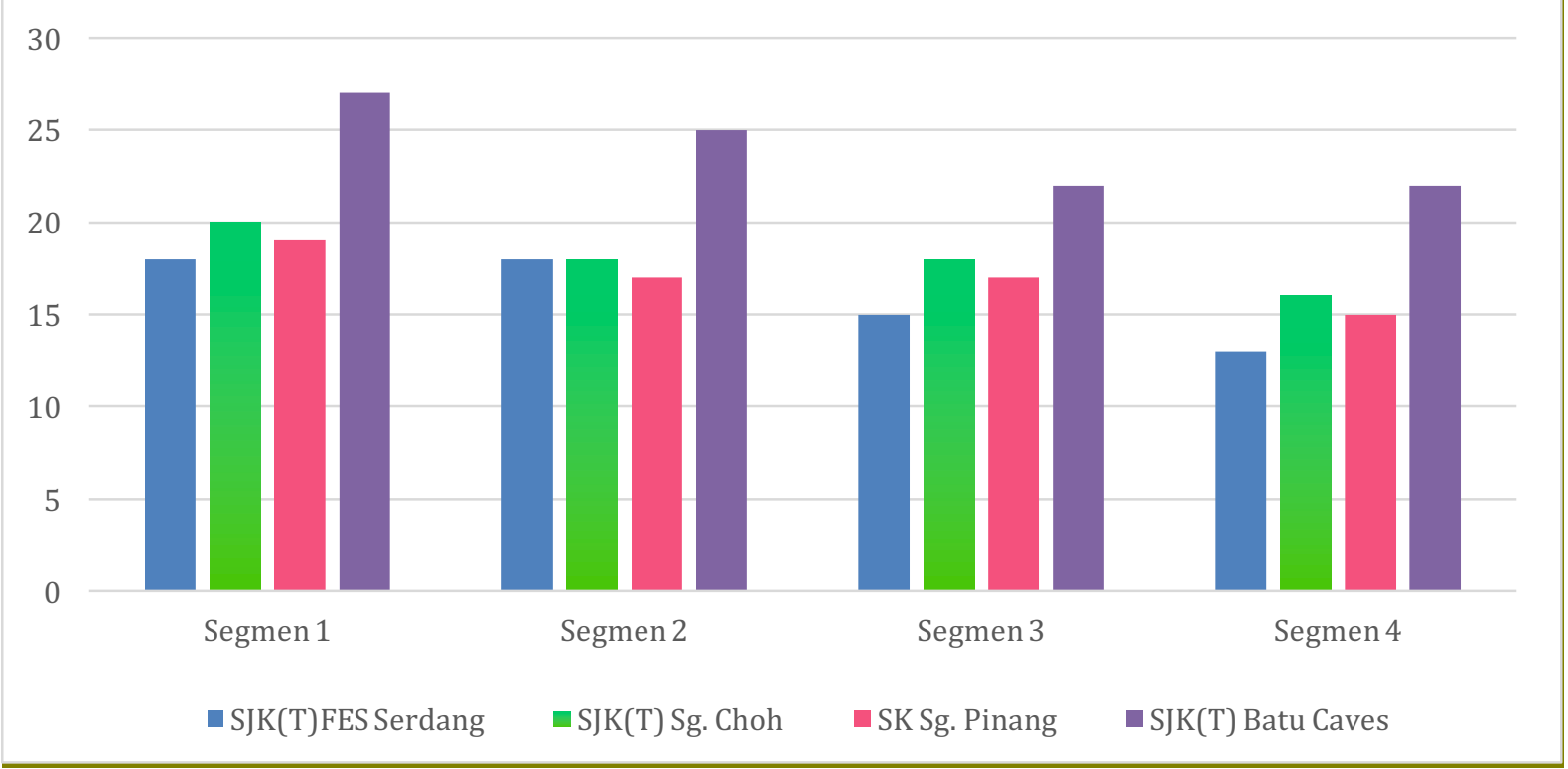

The graphs above shows students' reading levels before and after using LAMBM. Before using LAMBM in teaching and learning, it is found that only a small number of students from four schools have mastered skills in segment 1 dan a small number have mastered skills under segments 2 and 3. There is even no subject who masters the skills in segment 4. Compared to after using LAMBM, it can be seen the study subjects have demonstrated a very good performance when almost all subjects have mastered all four skills.

Other than that, through observation, the researcher discovers that students have given positive feedback. This is evident when the activities done are successful and are able to engage the interest of the students to take part voluntarily. Students are very active and they are willing to answer questions from researcher and read the syllables. They are always excited and do not show any sign of boredom because the teaching aid is colourful and interesting. They are not afraid to try and to make mistakes. Also, through observation, researcher finds that students are very interested in the objects. This is because they are able to touch, read and arrange the aids although some of them still fails to recognise letters. Researcher further finds that the use of LAMBM can be engaging and is able to build the confidence of weak and illiterate students to come forward and try these activities just like their other friends.

Other than choosing the students from the four schools as the subjects, the experiment using LAMBM is also done with 110 teachers from SJK(T) in districts of Pahang. Teachers are given the exposure with regard to the use of LAMBM teaching aid in teaching and learning. They are also trained to hold a tutorial concerning the ways of using the teaching aid. After the trial, teachers are given questionnaire in feedback forms for evaluation purposes. It contains 20 questions and divided into 5 sections. Section I is related to the Segment of Sound, Section II concerning Syllables Cards, Section III on Syllables Column Basic Board, while Section IV concerns with Syllables Consolidation Board and the final Section deals with Syllables Poster. Every section contains 4 questions. To evaluate the level of effectiveness, teachers are asked to choose the evaluation level scale for every item given. The scale encompasses Strongly Disagree (STS), Disagree (TS), Neutral (N), Agree (S) dan Strongly Agree (SS). 


\section{Teachers' Feedback}

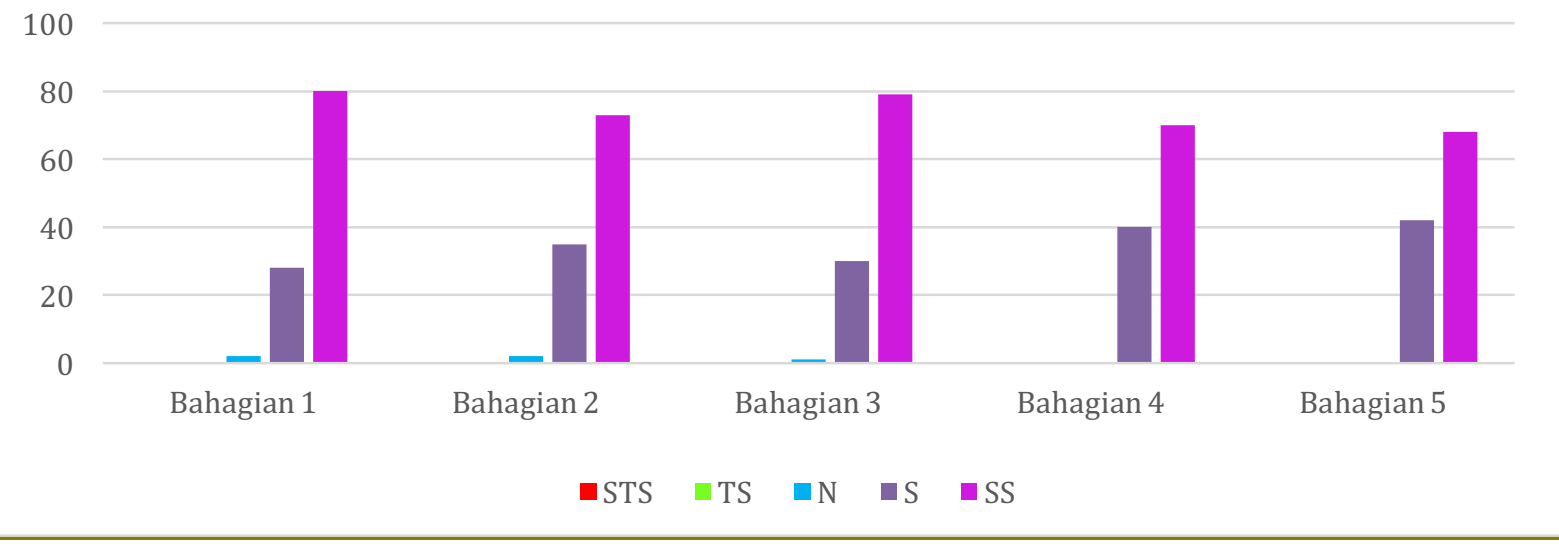

The graph above shows that 110 teachers have given their evaluation of the effectiveness of LAMBM aid through the feedback form. The following is the analysis in table form:

\begin{tabular}{|c|c|c|c|c|c|}
\hline SCALE & STS & TS & N & S & SS \\
\hline Section 1 & 0 & 0 & 2 & 28 & 80 \\
\hline Section 2 & 0 & 0 & 2 & 35 & 73 \\
\hline Section 3 & 0 & 0 & 1 & 30 & 79 \\
\hline Section 4 & 0 & 0 & 0 & 40 & 70 \\
\hline Section 5 & 0 & 0 & 0 & 42 & 68 \\
\hline
\end{tabular}

All in all, teachers agree and strongly agree with the use of this aid in teaching and learning. There are only few teachers who adopt a neutral attitude, whereas not one teacher disagrees or strongly disagrees with the use of this teaching aid in teaching and learning.

\section{CONCLUSION}

In brief, this study has successfully reduced the rate of illiteracy and the problem of not knowing how to read in Malay Language among students. Almost $90 \%$ of the target students for every school have mastered reading letters and syllables after using LAMBM teaching aid in teaching and learning in class. Other than that, the use of this teaching aid is also engaging to students where they get involved actively in the process. They do not show boredom or lack of interest to learn because the teaching aid helps them to focus better. The effectiveness of LAMBM is also supported by teachers. Almost 67\% teachers from the 110 people involved strongly disagree about the use of the teaching aid, while almost $32 \%$ agree and only $1 \%$ has a neutral attitude. In sum, no teacher disagrees or strongly disagrees about the use of the teaching aid.

\section{BIBLIOGRAPHY}

Abdul Rasid Jamian. (2011). Permasalahan Kajian Membaca dan Menulis Malay Language Murid-Murid School Rendah di Luar Bandar. Jurnal Pendidikan Malay Language. 1(1)(2011) : 1-12.

Kamarudin Haji Husin. (1998). Pedagogi Bahasa. Kuala Lumpur : Kumpulan Budiman.

Mohamad Sofee Razak. (2007, November 26). Intelek Kurang Membaca. Utusan Malaysia, 17.

Mohd Hafiz Mohamad Tarmizi. (2016). Level Kefahaman Membaca antara Murid Pasca Linus dan Murid Arus Perdana. Perak : Universiti Pendidikan Sultan Idris.

Nor Laila Kuslan. (2014). Aktiviti Pemulihan Bacaan di Sebuah School Rendah : Satu Kajian Kes. Kuala Lumpur : Universiti Malaya. 
Roslan Chin dan Nurahimah Yusoff. (2017). Penggunaan Strategi Pembelajaran Bahasa untuk Menguasai Skill Membaca dalam Kalangan Murid Pemulihan Khas. Kedah : Univerisiti Utara Malaysia.

Tamam Timbang, Zamri Mahamod dan Afendi Hamat. (2011). Faktor dan Kesan Masalah Membaca Murid-murid School Rendah Kerajaan di Brunei Darussalam. Jurnal Pendidikan Malay Language. 1(1)(2011): 89-107.

Tamam Timbang, Zamri Mahamod, Nik Mohd. Rahimi Nik Yusoff dan Jamaludin Badushah. (2010). Masalah Membaca Murid-murid School Rendah Kerajaan di Brunei Darussalam: Satu Kajian Kes. Jurnal Pendidikan Malaysia. 35(2)(2010): 77-85.

Tuzana Mohamad. (2014). Keberkesanan Modul Bacaan Bergred bagi Membantu Murid Linus Tegar dalam Skill Membaca KVKV. Pulai Pinang : Universiti Sains Malaysia.

Wan Mohd. Noor Wan Daud. (1994). Budaya Ilmu: Konsep, Prasyarat dan Pelaksanaan di Malaysia. Kuala Lumpur : Dewan Bahasa dan Pustaka. 